\title{
TOXIC ANTERIOR SEGMEN SYNDROME PASCA SMALL INCISION CATARACT SURGERY: LAPORAN KASUS
}

\author{
Esti Mahanani ${ }^{1,2}$, Alia Mabrouka ${ }^{1}$ \\ ${ }^{1}$ Departemen Ilmu Kesehatan Mata Fakultas Kedokteran Universitas Islam \\ Indonesia \\ ${ }^{2}$ Bagian Ilmu Kesehatan Mata RS Tidar Kota Magelang Jawa Tengah \\ Korespondensi: esti.emn@gmail.com
}

\begin{abstract}
ABSTRAK
Toxic anterior segmen syndrome (TASS) adalah suatu komplikasi inflamasi segmen anterior yang bersifat akut, steril, dan non infeksius yang bisa terjadi pada semua jenis operasi di segmen anterior. Kondisi ini mempunyai gambaran klinis yang mirip dengan endoftalmitis infeksius pada awal pasca operasi. Laporan kasus ini melaporkan suatu kasus TASS yang terjadi 20 jam pasca small incision cataract surgery. Kasus ini memberikan prognosis baik dengan terapi steroid topikal yang intensif.
\end{abstract}

Kata Kunci: TASS, endoftalmitis, terapi steroid. 


\title{
TOXIC ANTERIOR SEGMEN SYNDROME POST SMALL INCISION CATARACT SURGERY: CASE REPORT
}

\author{
Esti Mahanani ${ }^{1,2}$ Alia Mabrouka ${ }^{1}$ \\ ${ }^{1}$ Department of Ophthalmology Faculty Of Medicine Islamic University of \\ Indonesia \\ 2Department of Ophthalmology Tidar Regional Public Hospital Of Magelang Jawa \\ Tengah \\ Corespondence: esti.emn@gmail.com
}

\begin{abstract}
Toxic anterior segment syndrome is an acute, sterile, anterior segment inflammation that occurs after any anterior segment surgery. This condition has similar clinical presentation with infectious endopthalmitis at early hours after surgery. Here we report the clinical findings of a toxic anterior segment syndrome case in an adult with the similar presentation with infectious endopthalmitis at 20 hours after small incision cataract surgery. This case have good prognosis after intensive topical steroid therapy.
\end{abstract}

Keywords: TASS, endoftalmitis, steroid therapy. 


\section{PENDAHULUAN}

Dengan angka insidensi terbanyak sebagai penyebab kebutaan yang dapat ditangani diseluruh dunia, operasi katarak dengan implantasi lensa intraokular menjadi operasi terbanyak yang dilakukan dibidang mata. Dilaporkan sekitar 8000 kasus tiap 1 juta penduduk pertahun di Kanada, 7000 per juta orang di USA dan 9000 per juta orang di Australia telah dilakukan operasi Katarak. ${ }^{1}$

Operasi ini mempunyai angka kesuksesan yang tinggi dengan komplikasi yang jarang. Komplikasi tindakan operasi katarak pada umumnya bersifat berat dan ireversibel sehingga pencegahan lebih diutamakan. Komplikasi yang paling menjadi perhatian pasca operasi katarak adalah endoftalmitis infeksius karena komplikasi ini adalah komplikasi paling berat dan bersifat ireversibel dengan prognosis yang buruk. ${ }^{2,3,4}$ Walaupun insidensi endoftalmitis infeksius dilaporkan kecil berkisar $0,1 \%, 5$ tetapi karena buruknya prognosis menjadikan komplikasi yang serupa perlu diperhatikan sampai diagnosis endoftalmitis dapat disingkirkan. ${ }^{2}$

$$
\text { Toxic Anterior Segment }
$$

Syndrome (TASS), sering disebut juga endoftalmitis steril dan uveitis pasca operasi tanpa sebab yang jelas.6,7 TASS adalah suatu reaksi akut inflamasi segmen anterior yang biasanya terjadi setelah tindakan operasi segmen anterior dengan kejadian pasca operasi katarak yang terbanyak. Kondisi ini biasanya dimulai dari 12 sampai 48 jam setelah operasi, tetapi bisa juga terapi lebih lama. ${ }^{3}$

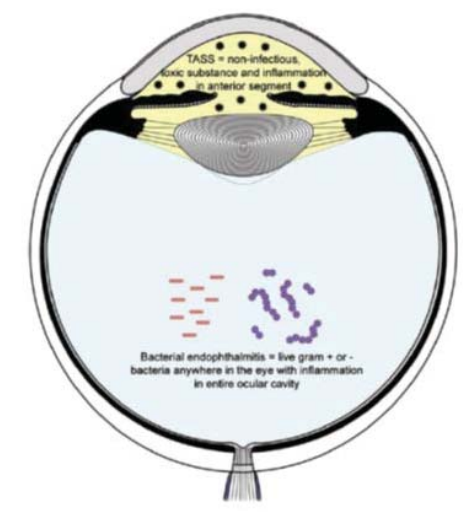

Gambar 1. Gambaran TASS dimana peradangan berat hanya terjadi pada segmen anterior sedangkan pada endoftalmitis akan terjadi sampai segmen posterior dengan keterlibatan bakteri infektif 8

Berbeda dengan endoftalmitis infeksius yang merupakan suatu bentuk inflamasi akut atau kronik yang berhubungan dengan infeksi bakteri patogen, TASS terbatas hanya pada segmen anterior seperti tercantum dalam Gambar 1. Gejala endoftalmitis meliputi nyeri ringan sampai berat, kehilangan penglihatan, floaters, fotofobia dan inflamasi segmen posterior sampai vitreus yang dibuktikan dengan pemeriksaan USG. Gejala lain meliputi udem periorbital, injeksi siliar, khemosis, reaksi segmen anterior, hipopion, udem kornea dan perdarahan retina hampir sama dengan kondisi klinis TASS. ${ }^{9}$

\section{LAPORAN KASUS}

Dilaporkan suatu kasus lakilaki usia 50 tahun dengan dengan keluhan kabur pasca operasi katarak 1 hari sebelumnya. Pada anamnesis didapatkan bahwa pasien menjalani operasi katarak pada mata kiri satu hari sebelumnya, keluhan kabur, 
nyeri ringan, dan silau. Kondisi preoperasi mata kiri katarak senilis imatur grade 3 dengan visus $3 / 60$, tekanan intraokular $12 \mathrm{mmHg}$, dengan lain-lain dalam batas normal. Pada mata kanan juga telah dilakukan operasi katarak 1 bulan sebelumnya dengan teknik dan operator yang sama tanpa komplikasi pasca operasi dengan visus koreksi 6/6. Pada pemeriksaan mata kiri 20 jam pasca operasi didapatkan visus handmovement dengan persepsi sinar dan warna baik, palpebra bengkak ringan, konjungtiva hiperemis, khemosis minimal, kornea udem diffuse dari limbus ke limbus, kondisi segmen anterior tidak terlalu jelas, dan didapatkan gambaran hipopion minimal $+2 \mathrm{~mm}$. Tekanan intraokular normal dengan palpasi. Pasien juga menderita gastritis akut pasca operasi karena analgetik asam mefenamat. Karena kondisi sistemik buruk dan pasien menolak dirujuk ke instansi yang lebih tinggi untuk evaluasi segmen posterior maka diputuskan untuk diobservasi sampai 48 jam pascaoperasi dengan terapi topikal moxifloksazin $6 \times 1$ tetes, neomisin dan deksametason $8 \times 1$ tetes dan siloxan $6 \times 1$ tetes. Terapi sistemik dihentikan karena iritasi lambung dan pasien di istirahatkan.

Pada follow up berikutnya 1 hari pasca operasi, didapatkan kondisi sistemik pasien membaik dengan visus menjadi 1/60 dengan status oftalmologis membaik hipopion tidak terlihat dan tekanan intraocular $16 \mathrm{mmHg}$ seperti tercantum dalam Gambar 2. Terapi dilanjutkan sama seperti hari sebelumnya. Pada hari ke 7 pasca operasi kondisi pasien membaik dengan visus 6/30 tidak bisa dikoreksi dengan konjungtiva hiperemis, kornea masih udem ringan dengan flare cell pada segmen anterior. Kondisi segmen posterior membayang dengan kesan normal seperti tercantum dalam Gambar 3. Pada follow up 1 bulan didapatkan visus koreksi bisa mencapai 6/6 dengan koreksi silinder C-2.

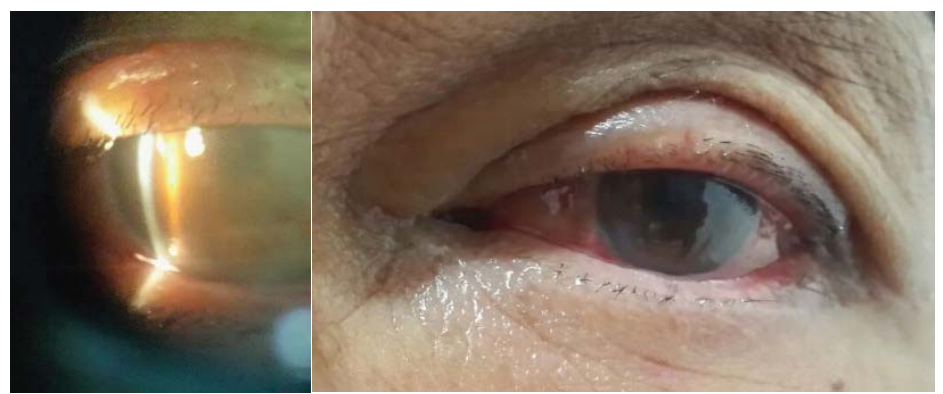

Gambar 2. Gambaran hari 48 jam pasca operasi. Palpebra udem, konjungtiva khemosis ringan, kornea udem diffuse, visus 1/60 dengan flare dan sel serta hipopion tidak terlihat, pupil mid-dilatasi $4 \mathrm{~mm}$ reflek positif.

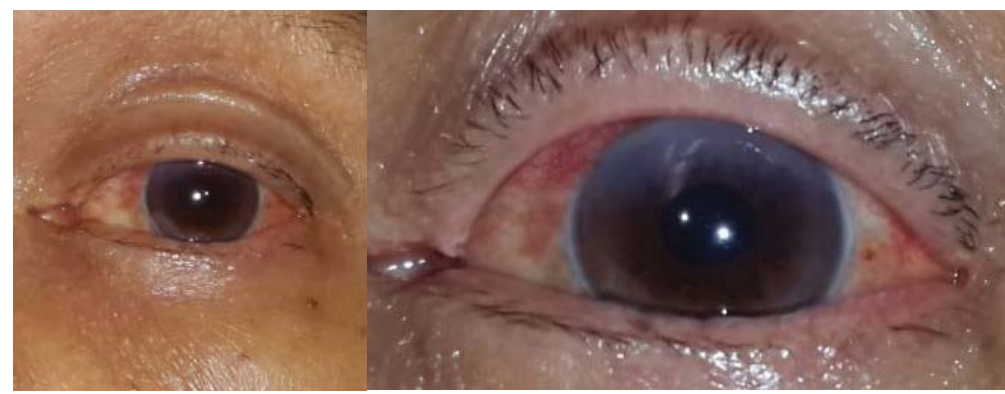

Gambar 3. Gambaran hari ke-7. Gambaran spasme palpebra, dan khemosis konjungtiva tidak ada, udem kornea berkurang, hipopion menghilang, pupil masih $4 \mathrm{~mm}$ ireguler. 


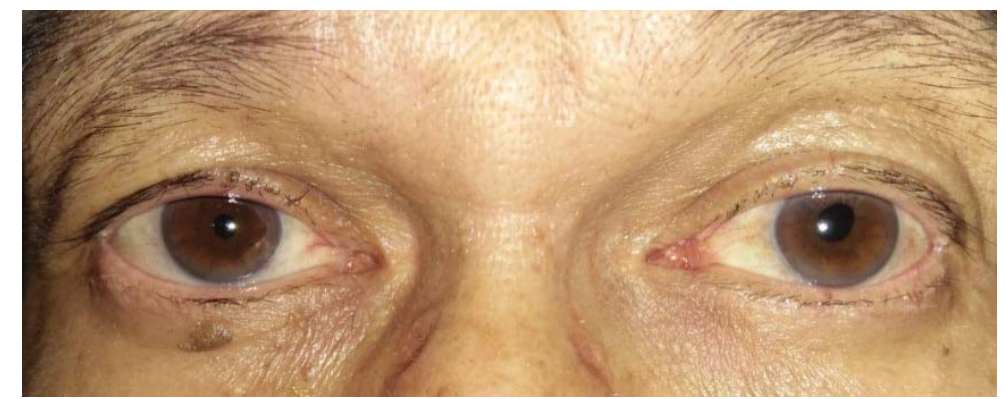

Gambar 4. Gambaran pada hari ke 28, pupil mata kiri diameter $4 \mathrm{~mm}$ reflek positif

\section{PEMBAHASAN}

TASS merupakan suatu komplikasi pasca operasi segmen anterior yang cukup jarang. Pada laporan kasus kali ini kami melaporkan suatu laporan kasus pasien dengan kecurigaan ke arah TASS pasca operasi katarak. Kondisi ini dikenali pada 20 jam pasca operasi dengan visus yang buruk dan nyeri ringan. Pada 20 jam pasca operasi berdasarkan kondisi klinisnya pasien didiagnosis dengan TASS dengan diagnosis banding dengan endoftalmitis infeksius dan diobservasi sampai hari ke-2 untuk tindakan lebih lanjut. Endoftalmitis merupakan suatu kondisi infeksi yang berat dan berbahaya sehingga kondisi pasca operasi segmen anterior dengan udem kornea dan hipopion seperti ini harus tetap menjadi diagnosis banding. Pada kondisi endoftalmitis dengan keterlibatan segmen posterior yang nyata dengan USG maka harus segera dilakukan injeksi intravitreal antibiotik broad spectrum pada visus $\geq 1 / 300$, dan vitrektomi pada visus 2LP. 9 Pasien diobservasi sampai 48 jam karena kondisi sistemik dengan gastritis akut karena analgetik pasca operasi. Pada kasus kali ini kami tidak langsung merujuk pasien, selain karena kondisi sistemik buruk pasien juga menolak dirujuk ke instansi lebih tinggi. Pasien ini diterapi dengan Moxiflosazin $6 \times 1$, cendo xitrol ${ }^{\circledR}$ per 3 jam, dan cendo $\operatorname{siloxan}^{\circledR} 4 \times 1$ terapi sistemik dihentikan. Kondisi ini sesuai dengan referensi bahwa kecurigaan endoftalmitis beserta tindakan progresif dilakukan setelah 48 jam pasca operasi, sedangkan pada kondisi kurang dari itu seperti pada pasien ini maka TASS masih menjadi suspek diagnosis paling kuat dan steroid intensif masih menjadi pilihan terapi utama. 1,9,8,10 Pada 48 jam pasca operasi kondisi visus sedikit membaik dengan 1/60 dan hipopion hampir menghilang tanpa rasa nyeri lagi. Pasien didiagnosis dengan TASS dan terapi steroid yang menjadi pilihan utama dilanjutkan. 8,11

Tanda khas yang penting yang menjadi dasar diagnosis kasus ini adalah adanya udem kornea disertai hipopion 20 jam pasca operasi katarak. Menurut Luz et al. (2014), hipopion merupakan suatu tanda khas yang selalu ada pada komplikasi operasi yang perlu diwaspadai, dari 21 pasien dengan komplikasi operasi meliputi endoftalmitis dan TASS serta kontrol 309 pasien pasca operasi. ${ }^{12}$ Hipopion terjadi pada 61,9\%, sedangkan hifema pada $12 \%$ pasien dengan komplikasi dan 0 pada pasien tanpa komplikasi, sementara tanda lain meliputi membran desmet, nyeri, edema kornea, edema kelopak mata, fibrin, flare sel, midriasis, keratic presipitate, reaksi anterior chamber, vitritis, kekeruhan vitreus, dan seidel positif msih ditemukan pada pasien control. ${ }^{12}$ 
Tabel 1. Perbedaan antara TASS dan Endoftalmitis infeksius. 1,13,14,15

\begin{tabular}{|c|c|c|}
\hline \multicolumn{3}{|c|}{ Diagnosis TASS vs endoftalmitis infeksius } \\
\hline Karakteristik & TASS & $\begin{array}{l}\text { Endoftalmitis } \\
\text { infeksius }\end{array}$ \\
\hline Onset & Hari 1-3 pasca operasi & Hari $\quad 3-7$ \\
\hline Gejala & Kabur & operasi \\
\hline Kornea & Edema +1 , dari limbus ke & Kabur dengan nyeri \\
\hline Segmen anterior & limbus & Edema +2 \\
\hline & Cell+1-3 & Cell+3 \\
\hline & Fibrin $+1-3$ & Fibrin bervariasi \\
\hline Vitreus & Hipopion+1 & Hipopion +3 \\
\hline Tekanan intraokular & Jernih & Vitritis \\
\hline $\begin{array}{ll}\text { Respon } & \text { terhadap } \\
\text { steroid } & \end{array}$ & $\begin{array}{l}\text { Terdapat kenaikan ringan TIO } \\
\text { Positif dan dramatis }\end{array}$ & $\begin{array}{l}\text { TIO } \\
\text { terpengaruh } \\
\text { Negatif }\end{array}$ \\
\hline
\end{tabular}

TASS : toxic anterior segmen syndrome

Pasien ini telah menjalani operasi mata kanan 1 bulan sebelumnya tanpa komplikasi. Seluruh faktor yang diduga terlibat meliputi teknik operasi, instrumen operasi, lokasi operasi dan operator sama identik pada kedua mata. Hal yang membedakan adalah penggunaan miostat yang telah digunakan satu hari sebelumnya dan disimpan dalam kotak steril. TASS dilaporkan salah satunya karena toxin yang masuk kedalam mata selama operasi meliputi bedak pada sarung tangan, instrument operasi, obat yang digunakan intraokular, bahan pengawet seperti benzalkonium chloride, konsentrasi antibiotik yang tidak benar, ophthalmic viscosurgical devices yang disterilkan, salep antibiotik pasca operasi, kebocoran luka, tekanan kassa dan reaksi imunitas terhadap sisa korteks bisa menyebakan terjadinya TASS. ${ }^{16,17}$ Kondisi toksik atau inflamasi pada segmen anterior akan menyebabkan kerusakan sel dan kerusakan ekstraselular. Endotel kornea adalah bagian yang mengalami kerusakan paling berat karena ketidakmampuan untuk beregenerasi dan menggantikan sel-sel mati. Agen toksik yang masuk pada saat intraoperative akan merusak endothelial junctions dan mengganggu sistem pumping sehingga terjadi edema kornea. ${ }^{14}$ Pada beberapa kasus berat glaukoma dan udem kornea yang permanen dilaporkan sebagai komplikasi yang persisten. Tidak ditemukan adanya hubungan sistemik pada kasus-kasus sebelumnya, tetapi diabetes dan hipertensi dilaporkan sebagai suatu faktor resiko yang signifikan. 10,11 

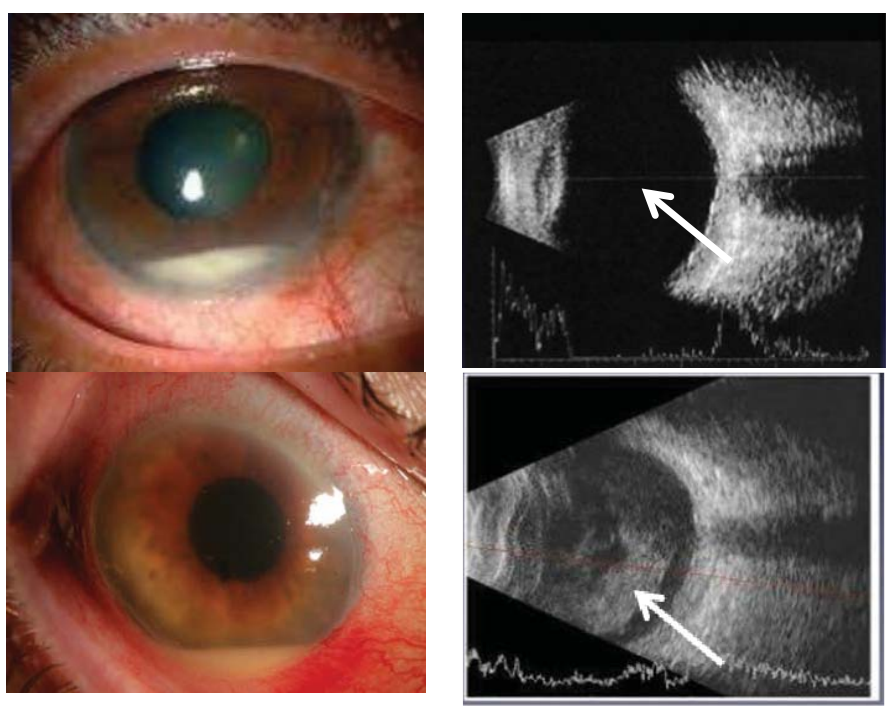

Gambar 5. Gambaran TASS (atas) dan endoftalmitis infeksius (bawah), beserta hasil USG dengan gambaran kekeruhan segmen posterior pada endoftalmitis dan jernih pada TASS (seperti anak panah). ${ }^{4,18}$

Tabel 2. Gambaran klinis TASS setelah operasi katarak dengan IOL on piece pada 251 mata. 15

\begin{tabular}{lc}
\hline & $\begin{array}{c}\text { Gejala klinis TASS } \\
\text { Gejala }\end{array}$ \\
\hline Sel inflamasi pada segmen anterior & N (\%) \\
Injeksi konjungtiva & $249(99,2)$ \\
Keratic precipitate & $104(41,4)$ \\
Fibrin & $70(27,9)$ \\
Hipopion & $67(26,7)$ \\
Kekeruhan vitreus & $57(22,7)$ \\
Edema kornea & $54(21,5)$ \\
\hline
\end{tabular}

Teknik operasi yang digunakan pada pasien ini pada kedua mata adalah small incision cataract surgery (SICS), dimana insisi dilakukan dengan membuat tunnel sklerokornea sepanjang sekitar $6 \mathrm{~mm}$, dan ditutup dengan 1 satu jahitan pada tengah insisi. Laporan tentang kejadian TASS pada SICS dibandingkan ECCE atau fakoemulsifikasi sejauh ini memang belum ada tetapi terkait dengan luka insisi yang lebih besar dari fakoemulsifikasi kemungkinan kejadian bisa lebih besar. Jika dilihat dari mata sebelah kanan yang sudah dioperasi 1 bulan sebelumnya tanpa ada masalah kejadian TASS ini memang menjadi perhatian lebih.
Pada 3 minggu pasca operasi didapatkan kondisi inflamasi sudah menghilang dengan visus koreksi OD C $-1,00$ dan OS C $-2,00$ bisa menjadi 6/6. Berdasarkan kondisi diatas, TASS yang terjadi pada pasien termasuk dalam klasifikasi moderat menurut Bansal and Moudgil (2015), dimana visus turun, udem kornea menghilang dalam hitungan minggu dan terdapat pengaruh peningkatan tekanan intraokular yang bisa dikendalikan dengan baik. ${ }^{14}$ Pada 3 minggu pasca operasi visus bisa menjadi 6/6 dengan koreksi silinder sehingga pasien didiagnosis dengan astigmatisma pasca operasi yang bisa terjadi karena beberapa hal meliputi teknik operasi, besar dan jenis insisi, 
jumlah jahitan, dan manipulasi intraoperatif yang dilakukan selama operasi. ${ }^{19,20,21}$

\section{KESIMPULAN}

Laporan kasus ini melaporkan suatu kasus laki-laki 50 tahun dengan TASS klasifikasi moderate yang terjadi pasca small incision cataract surgery. Pada kasus TASS yang moderate ini prognosis baik jika dilakukan penegakan diagnosis secepatnya, penanganan progresif antibiotik dan steroid yang tepat dan follow up yang baik. Komplikasi infeksi pasca operasi katarak harus ditangani dengan baik dan harus bisa dibedakan antara TASS dengan endoftalmitis yang memerlukan penanganan lebih serius.

\section{DAFTAR PUSTAKA}

1. Canadian Ophthalmological Society Cataract Surgery Clinical Practice Guideline. Canadian Ophthalmological Society evidence-based. CAN J OPHTHALMOL. 2008 Jan; 43.

2. Ayaki M, Shimada K, Yaguchi S, Koide R, Iwasawa A. Corneal and conjunctival toxicity of disinfectants-Assessing safety for use with ophthalmic surgical instruments. Regulatory Toxicology and Pharmacology j. 2007; 48: p. 292-297.

3. Diez R, Jordano L, Hita C. Toxic Anterior Segment Syndrome (TASS) and Prophylaxis Against Postoperative Endophthalmitis. [Online]. [cited 2015 August 18.

4. Ngoei E. Endophthalmitis. In ASCRS Cataract Clinical Committee; 2010; Miami USA.

5. Miller J, Scott I, Flyn J, Smiddy W, Newton J. Acute onset endophthalmitis after cataract surgery(2000-

2004):incidence,clinical settings, and visual acuity outcome after treatment. Am J Opthalmol. 2005; 139: p. 983-987.
6. Monson M, Mamalis N, Olson R. Toxic anterior segmen inflammation following cataract surgery. J. Cataract Refract Surg. 1992; 18: p. 184-189.

7. Lambert SR. Toxic anterior segment syndrome after pediatric cataract surgery. Journal of AAPOS. 2010 August; 8.

8. Mamalis $\mathrm{N}$, Edelhauser HF, Dawson DG, Chew J, LeBoyer RM, Werner L. Toxic anterior segment syndrome: review. Cataract and Ref surg. 2006; 32: p. 324-333.

9. AAO. American Academy of Opthalmology Basic and Clinical Course 2013-2014, Section 11 Lens and Cataract San Fransisco: American Academy of Opthalmology; 2012.

10. Kutty P, Forsten T, WoodKoob C. Multistate outbreak of toxic anterior segmen syndrome. J Cataract Refract surg. 2005; 34: p. 585-590.

11. Holland S, Morck D, Lee T. Update on toxic anterior segment syndrome. curr Opin Opthalmol. 2007; 18: p. 4-8.

12.Luz R, Padoveze MC, Silva E, Cvintal T. Endophthalmitis and Toxic Anterior Segment Syndrome After Cataract Surgery: Identification and Selection of Markers for Surveillance. In APIC 41st Annual Educational Conference \& International Meeting; 2014; Anaheim, CA.

13. Daly M. Solving TASS: Maximizing Patient Safety in VA Operating Rooms powerpoint presentation. [Online].; 2010 [cited 2015 August 29.

14. Bansal Y, Moudgil T. Toxic anterior segmen syndrome: review article. ijmds.org. 2015 July; 4.

15. Suzuki T, Ohashi Y, Oshika T, Goto H, Hirakata A, Fusuhita K, et al. outbreak of late-onset toxic anterior segment syndrome after implantation of one-piece 
intraocular lenses. Am J Opthalmol. 2015; 159 no 5.

16. Huang Y, Dai Y, Wu X, Lan J, Xie L. Toxic anterior segment syndrome after pediatric cataract surgery. Journal of AAPOS. 2010 September; 14.

17. Bodnar Z, Clouser S, Mamalis N. Toxic anterior segmen syndrome;Update on the most common causes. In ASCRS symposium on cataract IOL and refractive surgery; 2012; Illinois USA.

18. Raju N. Toxic anterior segmen syndrome power point presentation. [Online].; 2014 [cited 2015 september 25.

19. David LD, Phillips J. Wound Closure Manual Minnesota USA: Ethicon.inc a Johson and Johnson company; 2010.

20. Natchiar G. Manual Small Incision Cataract Surgery, An Alternative Technique to Instrumental Phacoemulsification. 1st ed. India: Aravind Eye Hospital; 2000.

21. Sukardi I, Hutahuruk J. Transisi Menuju Fakoemulsifikasi, Menguasai Teknik Teknik dan Menghindari Komplikasi. 1st ed. Jakarta: Universitas Indonesia Press; 2004. 